\title{
ANALISIS PENGEMBANGAN AGROWISATA UNTUK KESEJAHTERAAN MASYARAKAT DI KECAMATAN PETANG, KABUPATEN BADUNG
}

\author{
I Putu Danu Swastika ${ }^{1}$ \\ Made Kembar Sri Budhi \\ Made Henny Urmila Dewi ${ }^{3}$
}

${ }^{1}$ Fakultas Ekonomi dan Bisnis Universitas Udayana (Unud), Bali, Indonesia email: danuswastika@yahoo.co.id ${ }^{2}$ Fakultas Ekonomi dan Bisnis Universitas Udayana (Unud), Bali, Indonesia ${ }^{3}$ Fakultas Ekonomi dan Bisnis Universitas Udayana (Unud), Bali, Indonesia

\begin{abstract}
ABSTRAK
Penelitian ini bertujuan untuk menganalisis: 1) pengaruh kebijakan pemerintah terhadap entrepreneurship dan infrastruktur; 2) pengaruh kebijakan pemerintah, entrepreneurship dan infrastruktur terhadap pengembangan agrowisata; 3) pengaruh pengembangan agrowisata terhadap kesejahteraan masyarakat di Kecamatan Petang, Kabupaten Badung; 4) apakah kebijakan pemerintah berpengaruh tidak langsung terhadap pengembangan agrowisata melalui entrepreneurship dan infrastruktur; 5) apakah kebijakan pemerintah, entrepreneurship dan infrastruktur berpengaruh tidak langsung terhadap kesejahteraan masyarakat di Kecamatan Petang, Kabupaten Badung melalui pengembangan agrowisata. Teknik pengambilan sampel dengan Sampling Jenuh melibatkan 91 orang pekerja. Analisis data menggunakan PLS-SEM. Hasil penelitian bahwa kebijakan pemerintah berpengaruh positif dan signifikan terhadap entrepreneurship dan infrastruktur, tetapi berpengaruh tidak signifikan terhadap pengembangan agrowisata dan kesejahteraan masyarakat. Entrepreneurship berpengaruh positif dan signifikan terhadap pengembangan agrowisata, tetapi berpengaruh tidak signifikan terhadap kesejahteraan masyarakat. Infrastruktur berpengaruh positif dan signifikan terhadap pengembangan agrowisata, tetapi berpengaruh tidak signifikan terhadap kesejahteraan masyarakat. Pengembangan agrowisata berpengaruh positif dan signifikan terhadap kesejahteraan masyarakat.
\end{abstract}

Kata Kunci : kebijakan pemerintah, entrepreneurship, infrastruktur, pengembangan agrowisata, kesejahteraan masyarakat.

\begin{abstract}
This study aims to analyze: 1) the influence of government policy on entrepreneurship and infrastructure; 2) the influence of government policy, entrepreneurship and infrastructure on agro-tourism development; 3) the influence of agrotourism development on community welfare in Petang District, Badung Regency; 4) whether government policies have an indirect effect on the development of agro-tourism through entrepreneurship and infrastructure; 5) whether government policies, entrepreneurship and infrastructure have an indirect effect on the welfare of the people in Petang District, Badung Regency through the development of agro-tourism. Sampling technique with Saturated Sampling involved 91 workers. Data analysis using PLS-SEM. The result of research that government policy have positive and significant influence to entrepreneurship and infrastructure, but have no significant effect on agrotourism development and community welfare. Entrepreneurship has positive and significant impact on agro-tourism development, but has no significant effect on the welfare of the community. Infrastructure has positive and significant impact on agro-tourism development, but has no significant effect on the welfare of the community. Agro-tourism development has positive and significant impact on the welfare of the community.
\end{abstract}

Keywords : government policy, entrepreneurship, infrastructure, agro-tourism development, community welfare. 


\section{PENDAHULUAN}

Sejak Tahun 1960-an, pemerintahan di sejumlah negara berkembang telah memberikan perhatian terhadap pembangunan ekonomi yang bersumber dari pangsa pasar wisatawan internasional. Laporan Scheyvens (2011) menyatakan bahwa perdagangan ekspor barang primer dan sektor pariwisata telah memberikan kontribusi yang semakin penting pada pembentukan pendapatan dan perluasan penyerapan lapangan kerja.

Sharpley (2000) mengatakan banyak negara berkembang yang mempromosikan pariwisata, karena menawarkan potensi menciptakan lapangan kerja, meningkatkan pendapatan masyarakat dan pendapatan pemerintah. Booth (1990) dan Picard (1996) telah melaporkan trend pertumbuhan perjalanan wisata ke Indonesia, berkat bantuan lembaga internasional World Bank dan institusi lainnya. Sektor pariwisata dijadikan sebagai sektor andalan untuk mendulang devisa di tengah turunnya ekspor Indonesia akibat lesunya perdagangan dunia.

Menurut Evita dkk. (2012), manfaat ekonomi sektor pariwisata pada kenyataannya menimbulkan masalah pada berkurangnya sumber daya alam, masalah sosial budaya dan lingkungan, akibat daripada konsep pariwisata yang mengarah kepada pariwisata massal (mass tourism). Semakin parahnya kerusakan lingkungan, menuai banyak kritikan, sehingga pembangunan pariwisata sekarang ini, diarahkan pada pariwisata alternatif yang lebih peduli dengan kelestarian lingkungan, dengan menerapkan pariwisata berkelanjutan seperti pengembangan agrowisata. Utama (2011) mengatakan agrowisata merupakan pariwisata alternatif yang merupakan solusi masif dalam mengentaskan kemiskinan. 
Agrowisata telah dikembangkan sejak abad ke 20, dimana pariwisata dikaitkan dengan lingkungan produksi sektor pertanian (Zoto et al., 2013). Agrowisata didefinisikan semua aktivitas yang berkaitan dengan kegiatan wisata yang sekaligus menjadi pembelajaran bagi wisatawan dalam mengenal lebih dekat dengan proses produksi pada sektor pertanian dan menjadikan wilayah pertanian tersebut sebagai tempat menikmati hidangan produk pertanian secara langsung. Lobo et al. (1999) mengatakan dengan pengembangan agrowisata dapat memunculkan peluang bagi petani lokal, untuk meningkatkan pendapatan dan meningkatkan taraf hidup.

Hampton dan Jeyacheya (2015) mengatakan Bali adalah provinsi dengan kunjungan wisatawan asing terbesar dibandingkan dengan provinsi lainnya di Indonesia. Agrowisata sangat potensial dikembangkan di Bali sebagai diversifikasi produk wisata yang mulai digemari banyak wisatawan dan tersebar di beberapa kabupaten di Bali seperti: Lumbung Sari Agro, Agrowisata Teba Sari Bali, Agrowisata Jakawana, Bali Pulina Agrowisata, Wisata Agro Negari di Kabupaten Gianyar, Tur dan Pertanian Organik Kintamani di Kabupaten Bangli, Agrowisata Sibetan di Kabupaten Karangsem dan The Organic Farm Bali, The Sila's Agrotourism di Kabupaten Tabanan.

Kabupaten Badung yang sebagian besar pendapatan diperoleh dari sektor pariwisata. Perekonomian masyarakat terutama di Badung Selatan berkembang sangat pesat seiring berkembangnya pariwisata di kawasan ini. Namun berbeda dengan masyarakat Badung Utara seperti Kecamatan Petang yang tingkat kesejahteraannya masih jauh tertinggal dengan Badung Selatan. Menurut Diener 
et al. (2003), kesejahteraan merupakan salah satu kualitas hidup individu dan masyarakat, sehingga memunculkan satu kesimpulan bahwa kehidupan yang baik adalah kebahagiaan. Arie Kapteyn, James P. Smith dan Arthur van Soest pada Tahun 2009 menemukan bahwa faktor - faktor yang mempengaruhi kepuasan hidup global yaitu kebahagian yang dapat dijelaskan dengan 4 (empat) hal yaitu : pekerjaan atau aktivitas harian, interaksi sosial dan keluarga, kesehatan dan pendapatan.

Mata pencaharian utama masyarakat di Kecamatan Petang adalah sebagai petani yang pendapatan rendah sehingga masih banyak masyarakatnya hidup dalam kemiskinan. Berdasarkan basis data terpadu untuk program perlindungan sosial Tahun 2015 yang dikeluarkan oleh Tim Nasional Percepatan Penanggulangan Kemiskinan (TNP2K), rumah tangga sasaran di Kecamatan Petang adalah sebanyak 2.596 dari jumlah kepala keluarga di Kecamatan Petang pada akhir Tahun 2014 sebanyak 7.902 dengan pendidikan tertinggi yang ditamatkan pada jenjang tamatan sekolah dasar (BPS,2015).

Rendahnya tingkat pendidikan akan berpengaruh pada tingkat kesejahteraan masyarakat, dikarenakan rendahnya pendidikan sangat berhubungan dengan rendahnya kinerja dan produktifitas kerja yang berakibat pada rendahnya penerimaan pendapatan (Nehen, 2012). Kondisi kesejahteraan masyarakat di Kecamatan Petang juga diperburuk dengan masih kurangnya fasilitas pendidikan dan kesehatan yang sebagian besar tersedia di wilayah Badung Selatan.

Berdasarkan hal tersebut, peneliti sangat tertarik meneliti pengembangan agrowisata di Kecamatan Petang. Penelitian ini dilakukan di Desa Pelaga dan 
Desa Belok/Sidan, dikarenakan pada kedua desa ini terdapat usaha agrowisata yaitu Bagus Agro Pelaga dan Bali Eco Village serta memiliki jumlah penduduk miskin tertinggi di Kecamatan Petang bahkan hampir $50 \%$ dari total penduduk miskin di Kecamatan Petang berada di kedua desa ini. Selain itu, Pemerintah Kabupaten Badung akan menetapkan kedua desa ini menjadi Kawasan Daya Tarik Wisata Khusus (KDTWK) berupa kawasan agrowisata dan ekowisata berbasis pelestarian lingkungan, pariwisata kerakyatan, dan kearifan lokal, berdasarkan Peraturan Daerah Kabupaten Badung Nomor 26 Tahun 2013 tentang Rencana Tata Ruang Kabupaten Badung Tahun 2013 - 2033.

Damanik dan Weber (2006) mengatakan peran pemerintah dalam pengembangan pariwisata antara lain : pendampingan dalam promosi pariwisata, regulasi persaingan usaha dan pengembangan sumber daya manusia. Terkait dengan itu, maka Kebijakan Pemerintah Kabupaten Badung dalam pengembangan agrowisata yang mengandalkan pertanian adalah dengan meningkatkan produktifitas para petani melalui pembinaan, pelatihan, pendampingan, perbaikan jalan usaha tani dan bantuan peralatan kepada kelompok - kelompok tani. Promosi dilakukan dengan menyelenggarakan kegiatan pameran seperti Festival Pertanian Badung Utara yang dilaksanakan setiap tahun dengan mengambil lokasi di seputaran areal Jembatan Tukad Bangkung.

Namun pada kenyataannya, produk - produk pertanian masyarakat, belum banyak terserap dan petani sering kali kalah oleh ulah para tengkulak. Keadaan seperti ini sangat merugikan petani. Pemerintah seharusnya dapat membantu petani agar dapat menikmati manfaat yang besar dari hasil pertanian dan usaha 
pertanian masyarakat dapat mendukung pengembangan agrowisata, dimana terjalin kerjasama kemitraan yang kuat, dengan kesepakatan yang dapat memberi keuntungan bersama. Hal ini disebabkan karena ketidakseriusan pemerintah dalam melaksanakan kebijakan dan kurang memperhatikan keterlibatan masyarakat lokal, sehingga menimbulkan berbagai permasalahan dan kendala.

Permasalahan ini hanya bisa ditangani, kalau masyarakat lokal diberikan kesempatan dan dimampukan secara aktif dalam pembangunan pariwisata didaerahnya, atau apa yang dikenal dengan istilah pemberdayaan (Pitana, 2011). Scheyvens (2002) mengungkapkan bahwa pemberdayaan masyarakat dapat memberikan keuntungan yang berkelanjutan bagi masyarakat lokal. Pemberdayaan masyarakat miskin di pedesaan dapat dilakukan dengan pengembangan kewirausahaan (Wahyudin, 2012). Kewirausahaan menurut Zimmerer adalah suatu proses penerapan kreatifitas dan inovasi sehingga dapat memecahkan persoalan dan menemukan peluang untuk memperbaiki kehidupan (usaha). Zimmerer et al. (2008) juga mengatakan perubahan besar yang dihadapi wirausahawan saat ini yaitu pergeseran perekonomian dunia dari modal berbasis finansial ke modal berbasis intelektual. Dewasa ini, modal intelektual perusahaan semakin menjadi sumber keunggulan kompetitif di pasar.

Kewirausahaan erat kaitnya dengan sumber daya manusia, seperti yang dikatakan Hadiyati (2011) bahwa program kewirausahaan menjadi basis dalam pengembangan sumber daya manusia. Pendidikan kewirausahaan sangat berpengaruh dalam menumbuhkan niat berwirausaha (Adnyana dan Purnami, 
2016). Rendahnya pendidikan dan keterampilan masyarakat menyebabkan lemahnya tingkat kewirausahaan masyarakat di Kecamatan Petang.

Usaha agrowisata di Desa Pelaga dan Desa Belok/Sidan merupakan agrowisata yang berbasis modal, masyarakat masih sangat bergantung dan mengandalkan uluran tangan dari pihak swasta. Penyerapan tenaga kerja dari masyarakat lokal masih sangat sedikit yang kebanyakan hanya sebagai buruh tani. Partisipasi masyarakat setempat masih sangat kurang, sehingga masyarakat cenderung hanya sebagai penonton dan hanya sebagian kecil masyarakat yang terlibat dalam pengembangan pariwisata di daerahnya.

Pemerintah harusnya lebih sering melakukan kegiatan promosi dan lebih serius dalam pengembangan kewirausahaan masyarakat guna meningkatkan keterampilan dalam memajukan usaha. Selain itu, masyarakat harus didorong untuk menjalin kemitraan dengan pihak swasta dalam mengembangkan agrowisata. Pemerintah juga dapat mendorong pengembangan agrowisata berbasis masyarakat yang merupakan penerapan Community Based Tourism (CBT) sebagai pariwisata yang memperhitungkan aspek keberlanjutan lingkungan, sosial dan budaya (Suansri, 2003)

Meningkatnya kesejahteraan masyarakat pedesaan, mendorong para petani untuk terus menjaga pertaniannya, citra pertanianpun menjadi terangkat dan diharapkan akan mampu mendorong kembali minat para pemuda pedesaan untuk menggeluti pertanian serta mengurangi arus urbanisasi, sehingga konsep pariwisata berkelanjutan dalam mengembangkan agrowisata dapat terwujud. 
Ketersediaan dan kecukupan infrastuktur menjadi prioritas bagi pemerintah, karena berfungsi mendukung peran dunia usaha dalam meningkatkan pertumbuhan ekonomi (Indrawan, 2008). Temuan di lapangan, masih adanya akses langsung menuju lokasi obyek agrowisata dan pertanian masyarakat yang rusak serta telekomunikasi yang sering mengalami gangguan, akan menjadi kendala dalam kegiatan perekonomian dan pariwisata, karena memberikan pengalaman yang kurang menyenangkan dan mempengaruhi citra pariwisata. Sekali wisatawan mendapat kesan buruk, membutuhkan waktu lama untuk mengembalikannya.

Berdasarkan latar belakang diatas, dirumuskan pokok permasalahan yaitu 1) bagaimanakah pengaruh kebijakan pemerintah terhadap entrepreneurship dan infrastruktur? 2) bagaimanakah pengaruh kebijakan pemerintah, entrepreneurship dan infrastruktur terhadap pengembangan agrowisata? 3) bagaimanakah pengaruh pengembangan agrowisata terhadap kesejahteraan masyarakat di Kecamatan Petang, Kabupaten Badung? 4) apakah kebijakan pemerintah berpengaruh tidak langsung terhadap pengembangan agrowisata melalui entrepreneurship dan infrastruktur? 5) apakah kebijakan pemerintah, entrepreneurship dan infrastruktur berpengaruh tidak langsung terhadap kesejahteraan masyarakat di Kecamatan Petang, Kabupaten Badung melalui pengembangan agrowisata?

Penelitian ini bertujuan : 1) Menganalisis pengaruh kebijakan pemerintah terhadap entrepreneurship dan infrastruktur; 2) Menganalisis pengaruh kebijakan pemerintah, entrepreneurship dan infrastruktur terhadap pengembangan agrowisata; 3) Menganalisis pengaruh pengembangan agrowisata terhadap 
kesejahteraan masyarakat di Kecamatan Petang, Kabupaten Badung; 4) Menganalisis apakah kebijakan pemerintah berpengaruh tidak langsung terhadap pengembangan agrowisata melalui entrepreneurship dan infrastruktur; 5) Menganalisis apakah kebijakan pemerintah, entrepreneurship dan infrastruktur berpengaruh tidak langsung terhadap kesejahteraan masyarakat di Kecamatan Petang, Kabupaten Badung melalui pengembangan agrowisata.

\section{METODE PENELITIAN}

\section{Lokasi Penelitian, Populasi, Sampel, Metode Sampel}

Penelitian dilakukan di Desa Pelaga dan Desa Belok/Sidan, Kecamatan Petang karena mempunyai penduduk miskin terbanyak di Kecamatan Petang. Populasi diambil dari jumlah masyarakat yang bekerja pada usaha agrowisata yaitu Bagus Agro Pelaga di Desa Pelaga dan Bali Eco Village di Desa Belok/Sidan, Kecamatan Petang sebanyak 91 orang. Teknik pengambilan sampel menggunakan Non-Probability Sampling yaitu 91 orang.

\section{Metode Pengumpulan Data}

Metode pengumpulan data yang digunakan dalam penelitian ini adalah :

1) Observasi Non Partisipan, peneliti melakukan peninjauan ke lokasi sehingga diperoleh data berupa gambaran dan informasi kegiatan agrowisata di Kecamatan Petang, kebijakan pemerintah, kondisi geografis dan infrastruktur.

2) Interview (wawancara) dengan pelaku pariwisata, tokoh masyarakat dan aparat pemerintah 
I Putu Danu Swastika, Made Kembar Sri Budhi, Made Henny Urmila Dewi. Analisis ....

3) Kuesioner (angket) diberikan kepada masyarakat yang bekerja pada agrowisata yaitu Bagus Agro Pelaga di Desa Pelaga dan Bali Eco Village di Desa Belok/Sidan, Kecamatan Petang.

\section{Teknik Analisis Data}

SEM (Structural Equation Modelling) yang berbasis komponen dengan menggunakan Partial Least Squares (PLS) dipilih sebagai alat analisis.

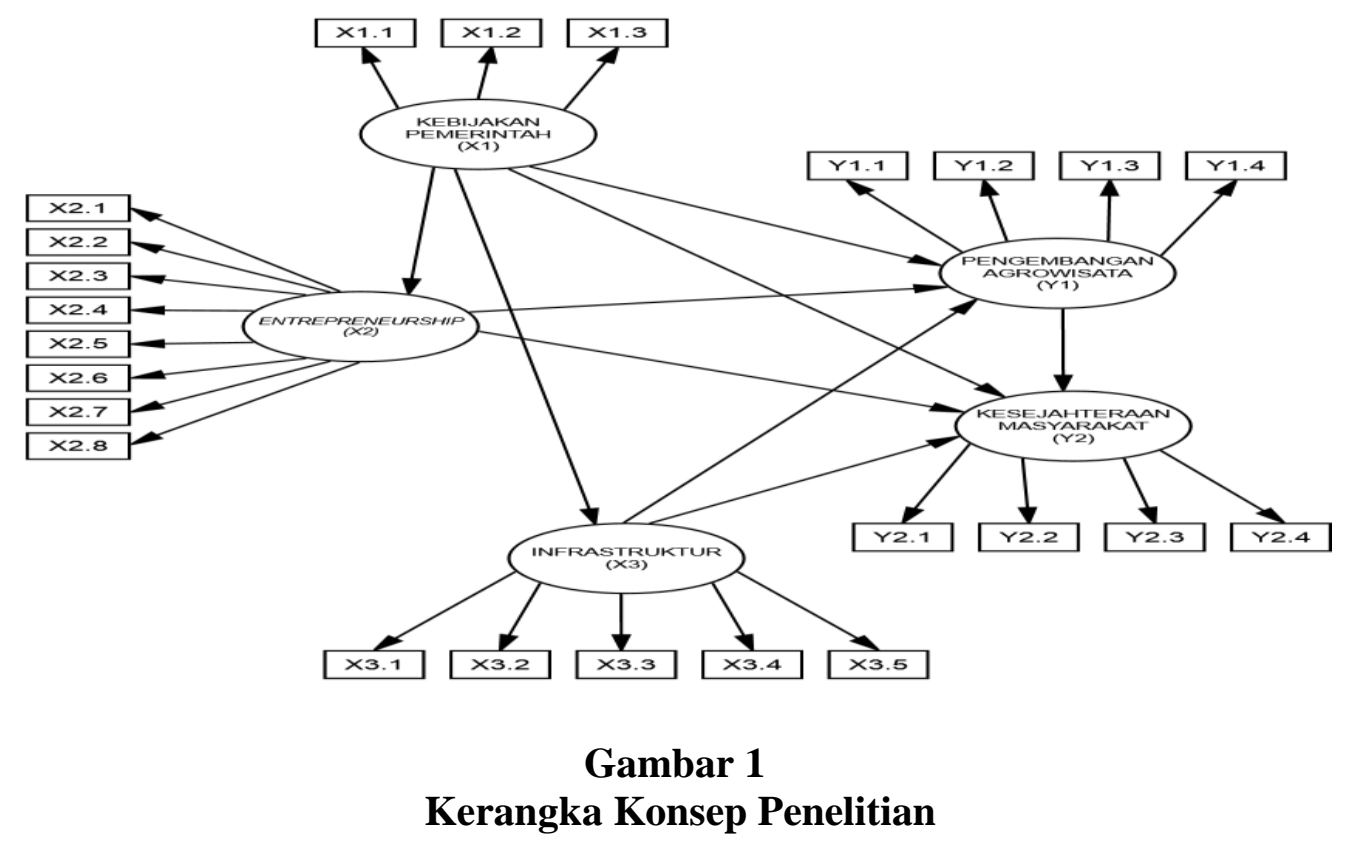

\section{HASIL DAN PEMBAHASAN}

\section{Pengaruh Langsung, Pengaruh Tidak Langsung,}

Pengaruh langsung antar variabel konstruk dapat dilihat dari hasil analisis nilai path coefficients yang ditampilkan pada Tabel 1. Dapat dijelaskan bahwa kebijakan pemerintah berpengaruh positif dan signifikan terhadap entrepreneurship dan infrastruktur, tetapi berpengaruh tidak signifikan terhadap pengembangan agrowisata dan kesejahteraan masyarakat. Demikian halnya 
variabel entrepreneurship berpengaruh positif dan signifikan terhadap pengembangan agrowisata, namun berpengaruh tidak signifikan terhadap kesejahteraan masyarakat. Selanjutnya juga terlihat bahwa infrastruktur berpengaruh positif dan signifikan terhadap pengembangan agrowisata, tapi berpengaruh tidak signifikan terhadap kesejahteraan masyarakat. Pengembangan agrowisata berpengaruh positif dan signifikan terhadap kesejahteraan masyarakat.

Tabel 1 Path Coefficient

\begin{tabular}{lccccc}
\hline & $\begin{array}{c}\text { Original } \\
\text { Sample (O) }\end{array}$ & $\begin{array}{c}\text { Sample } \\
\text { Mean (M) }\end{array}$ & $\begin{array}{c}\text { Standard } \\
\text { Deviation } \\
(\text { STDEV) }\end{array}$ & $\begin{array}{c}\text { T Statistics } \\
(\mid \mathbf{O} / \text { STDEV })\end{array}$ & P Values \\
\hline $\mathbf{X 1}$-> X2 & 0.757 & 0.759 & 0.056 & 13.574 & 0.000 \\
$\mathbf{X 1}$-> X3 & 0.597 & 0.589 & 0.073 & 8.161 & 0.000 \\
$\mathbf{X 1}$-> Y1 & 0.181 & 0.193 & 0.143 & 1.259 & $* 0.208$ \\
$\mathbf{X 1}$-> Y2 & 0.238 & 0.224 & 0.143 & 1.663 & $* 0.097$ \\
$\mathbf{X 2 ~ - > ~ Y 1 ~}$ & 0.272 & 0.264 & 0.114 & 2.391 & 0.017 \\
$\mathbf{X 2 ~ - > ~ Y 2 ~}$ & -0.084 & -0.083 & 0.100 & 0.839 & $* 0.402$ \\
$\mathbf{X 3}$-> Y1 & 0.348 & 0.347 & 0.093 & 3.734 & 0.000 \\
$\mathbf{X 3 ~ - > ~ Y 2 ~}$ & 0.022 & 0.019 & 0.086 & 0.260 & $* 0.795$ \\
$\mathbf{Y 1}$-> Y2 & 0.720 & 0.735 & 0.103 & 6.967 & 0.000 \\
\hline
\end{tabular}

Ket. *) Non Signifikan $(>0,05)$

Sumber: Lampiran 5

Sebaliknya pengaruh tidak langsung terjadi melalui peran satu atau beberapa variabel antara dan dapat dilihat dari hasil analisis nilai indirect effects yang ditampilkan pada Tabel 2, dan diketahui bahwa kebijakan pemerintah berpengaruh tidak langsung terhadap pengembangan agrowisata melalui infrastruktur. Kebijakan pemerintah juga berpengaruh secara tidak langsung terhadap kesejahteraan masyarakat melalui pengembangan agrowisata. Selanjutnya entrepreneurship berpengaruh tidak langsung terhadap kesejahteraan masyarakat melalui pengembangan agrowisata. Terakhir adalah bahwa 
infrastruktur juga berpengaruh tidak langsung terhadap kesejahteraan masyarakat melalui pengembangan agrowisata.

Tabel 2

Nilai Indirect Effects

\begin{tabular}{cccccc}
\hline & $\begin{array}{c}\text { Original } \\
\text { Sample (O) }\end{array}$ & $\begin{array}{c}\text { Sample } \\
\text { Mean (M) }\end{array}$ & $\begin{array}{c}\text { Standard } \\
\text { Deviation } \\
\text { (STDEV) }\end{array}$ & $\begin{array}{c}\text { T Statistics } \\
(\mid \mathbf{O} / \text { STDEV|) }\end{array}$ & P Values \\
\hline $\mathbf{X 1}$-> Y1 & 0.414 & 0.404 & 0.118 & 3.524 & 0.000 \\
$\mathbf{X 1}$-> Y2 & 0.378 & 0.388 & 0.124 & 3.042 & 0.002 \\
$\mathbf{X 2}$-> Y2 & 0.196 & 0.192 & 0.086 & 2.282 & 0.023 \\
$\mathbf{X 3}$-> Y2 & 0.251 & 0.253 & 0.075 & 3.361 & 0.001 \\
\hline
\end{tabular}

Sumber: Lampiran 5

Untuk menguji signifikansi hubungan, sangat penting memperhatikan nilai $p$-values, dimana hubungan dikatakan signifikan bila $p$-values $<0,05$, sebaliknya bila $p$-values $>0,05$ hubungan dikatakan tidak signifikan. Selanjutnya diperhatikan pula nilai $t$-statistic, dimana cut-off nya adalah dengan $t$-table senilai 1,67 .

\section{Kebijakan Pemerintah Berpengaruh Positif dan Signifikan terhadap Entrepreneurship}

Pengaruh kebijakan pemerintah terhadap entrepreneurship memiliki koefisien regresi sebesar 0,757 , dengan nilai $p$-values 0,000 yang lebih kecil dari 0,05. Nilai $t$-statistic juga lebih besar dari 1,67 yaitu senilai 13,574 . Jadi, secara langsung kebijakan pemerintah berpengaruh positif dan signifikan terhadap entrepreneurship. Hal ini sejalan dengan penelitian Firmansyah dkk. (2014), Samiadji et al. (2014) dan Wulandari (2014).

Berdasarkan Tabel 3, sebagian besar masyarakat yang bekerja di agrowisata adalah tamatan SMTA dan tamatan SD. Rotinsolu dkk. (2014) mengatakan masih kurangnya tenaga kerja terdidik yang terserap sebagai tenaga kerja berdampak pada lambatnya pertumbuhan dan pembangunan ekonomi, karena pendidikan 
sangat berpengaruh pada produktifitas, pendidikan menjadikan sumber daya manusia lebih cepat dan lebih siap dalam menghadapi perubahan dan pembangunan suatu negara, pemerintah perlu berperan aktif dalam meningkatkan kualitas pendidikan. Meningkatnya kualitas pendidikan akan menghasilkan lulusan siap kerja yang mempunyai jiwa kewirausahaan.

Kebijakan pemerintah dalam regulasi dengan pengurusan ijin usaha yang tidak rumit dengan membentuk Badan Perijinan Terpadu akan memberikan kemudahan bagi masyarakat dalam mendirikan dan mengembangkan usaha. Semakin banyak usaha yang tumbuh akan membuat kewirausahaan semakin berkembang yang mendukung kegiatan pariwisata dan meningkatkan perekonomian masyarakat di Kecamatan Petang.

Pemerintah dalam mengeluarkan peraturan - peraturan hendaknya mengarah pada kebijakan yang pro bisnis usaha mikro kecil dan menengah (UMK) seperti fasilitasi dalam kemudahan akses pembiayaan/permodalan, memperbanyak pelatihan - pelatihan teknis dan manajerial, mempermudah pengurusan perijinan, penyediaan sentra/lokasi usaha dan jaringan infomasi usaha (Munizu, 2010).

Tabel 3

Responden Berdasarkan Pendidikan

\begin{tabular}{|c|c|c|c|}
\hline No & Pendidikan & Frekuensi (orang) & Persentase $(\%)$ \\
\hline
\end{tabular}




\begin{tabular}{|c|c|c|c|}
\hline 1. & SD & 27 & 29,67 \\
\hline 2. & SLTP & 5 & 5,49 \\
\hline 3. & SLTA & 48 & 52,75 \\
\hline 4. & S1 & 10 & 10,99 \\
\hline \multirow[t]{2}{*}{5.} & $\mathrm{~S} 2$ & 1 & 1,10 \\
\hline & Jumlah & 91 & 100 \\
\hline
\end{tabular}

Sumber: Hasil Penelitian, 2016 (diolah)

Kebijakan Pemerintah Berpengaruh Positif dan Signifikan terhadap Infrastruktur

Pengaruh kebijakan pemerintah terhadap infrastruktur memiliki koefisien regresi sebesar 0,597 , dengan nilai p-values 0,000 yang lebih kecil dari 0,05 . Nilai t-statistic juga lebih besar dari 1,67 yaitu senilai 8,161. Jadi, secara langsung kebijakan pemerintah berpengaruh positif dan signifikan terhadap infrastruktur. Penyediaan infrastruktur yang memadai berupa jalan - jalan, listrik, air bersih dan telekomunikasi serta penunjuk arah, papan infromasi wisata, rambu lalu lintas wisata akan sangat mendukung dunia usaha dan semakin lancarnya kegiatan perekonomian masyarakat. Hal ini sesuai dengan penelitian Indrawan (2008), Rahimah dan Putro (2014).

Pentingnya peranan infrastruktur sebagai penggerak roda perekonomian membuat pemerintah menjadikan ketersediaan infrastruktur yang memadai sebagai prioritas harus segera dilaksanakan. Infrastruktur menyangkut akses jalan menuju lokasi obyek agrowisata dan telekomunikasi di Desa Belok/Sidan, yang masih sering mengalami gangguan, Bapak I Wayan Surat Oka Negara,ST.,Msi., Kabid Prasarana dan Sarana pada Bappeda Litbang Kabupaten Badung pada saat wawancara pada tanggal 7 Desember 2016, mengatakan :

"Infrastruktur yang sudah dibangun oleh Pemerintah Kabupaten Badung sudah sangat mendukung pengembangan pariwisata. Mengenai jalan menuju akses obyek agro di Desa Belok/Sidan yang rusak, apabila jalan mempunyai status hukum yang jelas yaitu jalan desa, bukan milik pribadi itu dapat diperbaiki 
melalui anggaran yang ada di desa kalau memungkinkan, kalau tidak, nanti bisa dianggarkan di Kabupaten. Apabila jalan itu jalan pribadi tentunya harus dibuatkan kesepakatan untuk dihibahkan ke desa. Masalah telekomunikasi, pada Tahun 2017 pemerintah Kabupaten Badung akan bekerja sama dengan pihak swasta dalam penyediaan telekomunikasi yang lebih baik sehingga bisa menjangkau semua kawasan.”

\section{Kebijakan Pemerintah Berpengaruh Positif dan Signifikan terhadap Pengembangan Agrowisata}

Pengaruh kebijakan pemerintah terhadap pengembangan agrowisata memiliki koefisien regresi sebesar 0,181 , dengan nilai p-values 0,208 yang lebih besar dari 0,05. Nilai t-statistic lebih kecil dari 1,67 yaitu senilai 1,259. Jadi, secara langsung kebijakan pemerintah berpengaruh tidak signifikan terhadap pengembangan agrowisata. Hal ini kurang sejalan dengan penelitian dilakukan oleh Seetanah et al. (2011), Parma (2013), Mouw dan Djurubasa (2014), dikarenakan pemerintah masih kurang optimal dalam melakukan promosi. Selain mengadakan pameran dan memperkenalkan destinasi agrowisata dalam setiap kegiatan kepemerintahan baik berskala regional, nasional dan internasional seperti pada acara rapat - rapat/pertemuan penting, pemerintah dapat melakukan terobosan dengan pengembangan promosi pariwisata secara digital.

Semakin berkembangnya media sosial saat ini, merupakan peluang yang dapat dimanfaatkan dalam promosi pariwisata. Pemerintah melalui Dinas Pariwisata dapat membuat Tourist Information Center dalam bentuk digital yang terhubung dengan media sosial dengan konten Tourist Information Service yang terhubung dengan media sosial dan website yang dapat diakses oleh wisatawan dan pelaku pariwisata. Promosi menjadi lebih efektif dikarenakan promosi tidak hanya dilakukan oleh pelaku pariwisata tetapi juga para pengguna media sosial. 
Pemanfaatan media sosial sebaiknya tidak hanya sebatas penyampaian informasi tentang produk atau jasa pariwisata yang hanya fokus pada penjualan, tetapi juga dengan social strategy untuk menjaga hubungan pelaku pariwisata dengan wisatawan dapat terjalin dengan baik (Umami, 2015).

Kebijakan pemerintah dalam regulasi juga masih kurang dikarenakan kurang memberikan keleluasaan bagi pengusaha dalam menjalankan kegiatan usahanya, pemerintah masih sangat kaku dan belum mampu mengakomodir keinginan para investor seperti pada regulasi pemanfaatan ruang yang hanya boleh $2 \%$ dari luas kawasan obyek agrowisata. Hal serupa yang dikatakan oleh Bapak I Gusti Bagus Sumartana, Aktivity Manager Bagus Agro Pelaga pada saat wawancara pada tanggal 9 Desember 2016 yaitu :

“Angka $2 \%$ untuk pemanfaatan ruang masih sangat kecil, kalau bisa angkanya dinaikkan lagi, lahan kami yang cuma $18 \mathrm{Ha}$ dengan angka $2 \%$ masih sangat terlalu kecil, kami sudah mengajukan permohonan untuk penambahan beberapa fasiltas wisata namun ditolak, Jika masih dipertahankan seperti ini, harapan untuk meningkatkan kesejahteraan masyarakat setempat masih sangat jauh karena sangat sulit untuk mengajak wisatawan dari Nusa Dua atau Kuta untuk datang kesini dengan jarak yang cukup jauh dan hanya untuk melihat produk holtikultura tanpa didukung fasilitas pariwisata yang lebih lengkap."

Tentunya pemerintah tidak mau keluar dari aturan yang ada, sehingga harus dicarikan jalan keluar dengan duduk bersama antara pemerintah, investor dan masyarakat untuk menemukan solusi terbaik, agar kegiatan pengembangan pariwisata tetap memperhatikan fungsi dan daya dukung lingkungan, mengedepankan keterlibatan masyarakat lokal serta keberlanjutan pariwisata.

Kebijakan pemerintah dalam pengembangan sumber daya manusia masih harus ditingkatkan karena masyarakat setempat belum mampu mengelola sumber daya alam dan budaya yang ada secara mandiri. Usaha - usaha agrowisata harus 
dibangkitkan lagi dengan membangun desa wisata yang menjadikan agrowisata dan kearifan lokal sebagai daya tarik utama. Kewirausahaan masyarakat harus terus ditingkatkan melalui pembinaan dan pelatihan yang lebih serius sehingga mampu mengelola sumber daya alam dan budaya menjadi paket wisata yang menarik. Pemerintah juga dapat bekerja sama dengan pihak swasta menjual paket - paket wisata ke Badung Utara. Desa wisata ini harus dijadikan bagian dari paket wisata yang wajib dikunjungi, sehingga secara rutin dapat menghadirkan wisatawan yang berdampak bagi perekonomian dan kesejahteraan masyarakat.

Pemerintah harus mendorong kerjasama masyarakat dengan swasta dalam pengolahan dan pemasaran produk pertanian masyarakat. Kemauan berbagi pihak swasta dengan masyarakat dalam bisnis pariwisata masih kurang. Kesempatan yang sebenarnya bisa membuat masyarakat ambil bagian dalam kegiatan pariwisata masih sangat terbatas.

Banyaknya lahan pertanian yang dijual ke pihak luar untuk dibangun sarana pariwisata, ada juga yang dikelola kembali oleh pihak luar dan malahan masyarakat setempat menjadi buruh tani pada lahan yang telah dijualnya, hal ini tidak semestinya terjadi. Peran dan dukungan pemerintah harusnya lebih serius dalam penegakkan aturan dan mendorong pengembangan agrowisata berbasis masyarakat dengan meningkatkan nilai fungsi lahan sehingga meningkatkan pendapatan petani. Agrowisata berbasis masyarakat sebagai bentuk penerapan Community Based Tourism (CBT) sangat sesuai dikembangkan di Kecamatan Petang, sebagai antisipasi terhadap pemindahan kepemilikan dan alih fungsi lahan 
serta perlindungan lahan pertanian masyarakat akibat permintaan industri pariwisata dan pengembangan pemukiman.

Pengembangan agrowisata di Kecamatan Petang kurang menerapkan konsep Community Based Tourism (CBT), dikarenakan partisipasi masyarakat dalam pengembangan pariwisata masih sangat kecil. Masyarakat hanya berperan sebagai tenaga kerja dengan penyerapan yang masih sedikit. Belum banyak masyarakat yang mampu memanfaatkan peluang dari kehadiran wisatawan. Masyarakat belum punya kesiapan dalam kegiatan pariwisata.

Masyarakat pedesaan di sekitar tempat pariwisata paling tidak dapat berpartisipasi dalam menciptakan keamanan, ketertiban, kebersihan, kesejukkan, keindahan, keramahtamahan dan dapat memberi kenangan yang mengesankan bagi wisatawan yang dikenal dengan Program Sapta Pesona, sehingga akan mendukung kegiatan pariwisata di daerahnya. Hal ini akan menjadi promosi yang efektif dalam pengembangan pariwisata.

\section{Entrepreneurship Berpengaruh Positif dan Signifikan terhadap Pengembangan Agrowisata}

Pengaruh entrepreneurship terhadap pengembangan agrowisata memiliki koefisien regresi sebesar 0,272 , dengan nilai p-values 0,017 yang lebih kecil dari 0,05. Demikian halnya nilai $t$-statistic juga lebih besar dari 1,67 yaitu senilai 2,391. Jadi, secara langsung entrepreneurship berpengaruh positif dan signifikan terhadap pengembangan agrowisata. Hal ini sesuai dengan penelitian Dinata dkk.(2011), Dumasari dan Watemin (2013), dimana seiring dengan meningkatnya kewirausahaan, masyarakat akan mampu terlibat lebih luas dalam aktivitas pariwisata. 
Hal ini juga sejalan dengan hasil wawancara dengan Hendri Isdariyatno, manager pada Bali Eco Village pada saat wawancara pada tanggal 7 Juli 2016 mengatakan :

"Perbaikan beberapa fasilitas pariwisata disini dan juga penataan tanaman sayur - sayuran adalah dalam rangka memberikan pelayanan yang lebih baik guna pengembangan obyek"

Kemudian Bapak I Gusti Ngurah Wijaya, Front Office Manager di Bagus Agro Pelaga pada saat wawancara pada 9 Desember 2016 yang mengatakan bahwa :

"Pelayanan yang baik kepada wisatawan sangat mendukung pengembangan agrowisata, para karyawan telah kami berikan pelatihan - pelatihan dan baru baru ini beberapa orang juga telah mengikuti sertifikasi kompetensi tenaga kerja pariwisata."

Meningkatnya kewirausahaan dengan diikutsertakannya para karyawan dalam pelatihan - pelatihan akan menjadikan para karyawan sebagai tenaga kerja yang handal, mempunyai visi yang tajam, perencanaan yang matang, motivasi yang tinggi, mampu berinovasi, mampu memanfaatkan peluang, mempunyai kepercayaan diri yang tinggi, berani mengambil resiko serta mampu beradaptasi terhadap setiap perubahan pengetahuan dan teknologi dalam melakukan pekerjaan sehingga menunjang kinerja karyawan dalam menjalankan tugas dan tanggung jawab yang dibebankan didalam mencapai tujuan yang ditetapkan oleh perusahaan dalam rangka pengembangan agrowisata.

Infrastruktur Berpengaruh Positif dan Signifikan terhadap Pengembangan Agrowisata

Pengaruh infrastruktur terhadap pengembangan agrowisata memiliki koefisien regresi sebesar 0,348 , dengan nilai p-values 0,000 yang lebih kecil dari 
0,05 . Demikian halnya nilai $t$-statistic juga lebih besar dari 1,67 yaitu senilai 3,734. Jadi, secara langsung infrastruktur berpengaruh positif dan signifikan terhadap pengembangan agrowisata. Infrastruktur yang baik akan memberikan kenyamanan dalam berwisata dan menjadi penentu kedatangan wisatawan. Hal ini mendukung penelitian sebelumnya oleh Sudiarta (2005), Seetanah et al. (2011), Valeriani (2011) dan Bascavusoglu-Moreau et al. (2013). Hal ini juga diperkuat dengan oleh Agung Widia Muncana, Proverty Manager Bagus Agro Pelaga dalam wawancara pada tanggal 9 Desember 2016 bahwa :

"Infrastruktur sekarang sudah lebih baik sehingga memberikan kemudahan dan kenyamanan bagi wisatawan yang datang kesini, jalan - jalan sudah bagus, air kami langsung mengambil dari mata air, listrik ga pernah mati, telepon dan internet juga cukup baik."

Temuan di lapangan bahwa infrastruktur di Kecamatan Petang meliputi jalan, listrik, air bersih, telekomunikasi, penunjuk arah, papan informasi wisata, rambu lalu lintas wisata memang sudah cukup memadai. Akses jalan menuju Bali Eco Village di Desa Belok/Sidan masih rusak, telepon dan internet masih sering mengalami gangguan bahkan masih ada blank spot. Hal ini diperkuat dengan pernyataan yang disampaikan oleh Hendri Isdariyatno, manager pada Bali Eco Village pada saat wawancara pada tanggal 7 Juli 2016 mengatakan :

"Infrastruktur jalan menuju kesini masih sangat rusak dikarenakan kami masih dalam pembangunan dan perbaikan beberapa fasilitas dan akan kami perbaiki lagi setelah semuanya selesai. Internet memang kadang- kadang kurang bagus dan menjadi kendala dalam aktifitas pariwisata."

Masalah aksesbilitas harus mendapat perhatian karena berpengaruh besar bagi wisatawan. Semakin baik aksesbilitas semakin banyak jumlah wisatawan 
yang dapat berkunjung, begitu juga sebaliknya jika aksesbilitas buruk, wisatawan akan mengalami hambatan dalam berkunjung ke obyek wisata (Widiarta,2015)

Kemudian dalam wawancara dengan Bapak I Made Resi, Sekretaris Desa Belok/Sidan di Kantor Perbekel Desa Belok/Sidan pada 9 Desember 2016 juga mengatakan :

"Telepon disini memang sering gangguan, bahkan internet tidak berfungsi, kami sudah punya perangkat komputer yang mendukung internet, namun koneksi belum ada."

Masalah komunikasi juga harus secepat mungkin mendapat penanganan, karena berperan penting dalam mendorong perekonomian masyarakat dan kemajuan pariwisata. Hal ini juga menjadi kendala bagi masyarakat desa yang sudah banyak memanfaatkan sarana komunikasi seperti telepon genggam dalam menjual dan memasarkan produk - produk pertaniannya. Begitu juga dengan pengusaha pariwisata akan kesulitan dalam menjalankan kegiatan usahanya.

\section{Pengembangan Agrowisata Berpengaruh Positif dan Signifikan terhadap Kesejahteraan Masyarakat di Kecamatan Petang, Kabupaten Badung}

Pengaruh pengembangan agrowisata terhadap kesejahteraan masyarakat di Kecamatan Petang, Kabupaten Badung memiliki koefisien regresi sebesar 0,720, dengan nilai $p$-values 0,000 yang lebih kecil dari 0,05 . Demikian halnya nilai $t$ statistic juga lebih besar dari 1,67 yaitu senilai 6,967. Jadi, secara langsung pengembangan agrowisata berpengaruh positif dan signifikan terhadap kesejahteraan masyarakat di Kecamatan Petang, Kabupaten Badung.

Kerjasama antar pemerintah, swasta dan masyarakat sangat diperlukan untuk keberlanjutan pariwisata, begitu juga dengan pengembangan agrowisata. 
Upaya pengembangan agrowisata dilakukan dengan pengembangan daya tarik, peningkatan akses, penambahan fasilitas penunjang dan penguatan kelembagaan. Daya tarik yang sudah ditawarkan seperti wisata ke lahan pertanian untuk tujuan pendidikan tentang pertanian organik dari pembibitan, menanam, dan perawatan tanaman, trekking, cycling, outbond, belajar memasak tradisional, memetik buah, sayur dan bunga. Budidaya tanaman seperti strowberry, jeruk, pepaya, jambu, asparagus, wortel, brokoli, sawi, kol, dan bunga mawar.

Kemudian untuk lebih menarik kunjungan wisatawan, pihak investor mengembangan daya tarik yang lain seperti aktivitas yoga, layanan SPA, penataan dan menambah beberapa jenis tanaman seperti Jeruk Dekovon dan sayur sayuran, serta berwisata ke obyek wisata lainnya sesuai pesanan ataupun jalan jalan di lingkungan penduduk sekitarnya. Pemerintah juga berusaha meningkatkan kualitas dan kuantitas produk pertanian masyarakat, penataan Jembatan Tukad Bangkung dan Pura Luhur Pucak Mangu guna menarik minat wisatawan untuk berkunjung ke daerah - daerah sekitar agrowisata.

Untuk memudahkan wisatawan mencapai lokasi agrowisata, investor melakukan peningkatan akses dengan penataan jalan menuju obyek agrowisata, perbaikan pintu masuk keluar obyek agrowisata, penataan jalan - jalan setapak di areal obyek agrowisata. Pemerintah daerah juga berusaha mempermudah akses ke lokasi agrowisata dan daerah - daerah sekitarnya dengan melakukan penataan dan pemeliharaan jalan serta membangun Jembatan Tukad Bangkung yang memperlancar arus lalu lintas pariwisata dan perekonomian masyarakat. 
Untuk memenuhi kebutuhan wisatawan, investor juga menambah fasilitas penunjang pariwisata seperti memperluas restoran dan tempat rapat, menambah jumlah kamar, menyediakan fasilitas yoga serta memperluas lahan parkir. Dukungan dari pihak pemerintah dalam menunjang aktivitas pariwisata di Kecamatan Petang dengan menambah fasiltas umum seperti toilet umum dan lahan parkir di seputaran Tukad Bangkung sehingga menambah kenyamanan dalam berwisata.

Kelembagaan diperlukan dalam memperlancar operasional obyek agrowisata melalui pembentukan struktur organisasi yang melayani dan memberikan kenyamanan bagi wisatawan. Sedang pemerintah daerah dalam memperkuat kelembagaan pariwisata di masing - masing desa dengan membentuk Kelompok Sadar Wisata (Pokdarwis) sebagai pendorong dan penggerak utama dalam kegiatan pariwisata di Kecamatan Petang.

Pengembangan agrowisata memberikan peningkatan bagi usaha agrowisata sehingga masyarakat di Kecamatan Petang memperoleh keuntungan ekonomi dalam penyediaan lapangan kerja dengan menyerap tenaga kerja yang semakin banyak seperti sebagai pengolah lahan pertanian di obyek agrowisata, gardener and estetika, maintenance and security, food and beverage, housekeeping, front office, admin dan pemandu wisata.

Meningkatnya usaha agrowisata memberikan dampak bagi peningkatan pendapatan masyarakat yang bekerja di obyek agrowisata, sekaligus dapat meningkatkan kesejahteraannya. Hal ini sesuai dan mendukung penelitian yang dilakukan oleh Waspada (2008) dan Luthfi (2013). Dari hasil wawancara dengan 
Ketua Pokdarwis Desa Belok/Sidan yaitu Bapak Drs. I Ketut Sueta, pada tanggal

17 Juli 2016 juga mengatakan hal yang sejalan yaitu :

"Adanya agrowisata di sini, kami dan seluruh masyarakat desa merasa sangat terbantu karena disamping menyediakan lapangan pekerjaan, adanya kerjasama dengan desa adat dan desa adat memperoleh kontribusi sehingga memberikan keringanan bagi warga kami dalam kegiatan - kegiatan adat. Kesejahteraan mulai meningkat terbukti dengan kondisi rumah - rumah masyarakat yang semakin baik."

Pendapat yang sama juga disampaikan oleh Bapak Dewa Ngakan Made

Merta Ekayasa, Kaur Pembangunan Desa Pelaga pada saat wawancara pada tanggal 9 Desember 2016 yang mengatakan :

"Adanya pengembangan agrowisata di Desa Pelaga mampu meningkatkan kesejahteraan masyarakat melalui penyediaan lapangan kerja seperti sebagai pengolah lahan pertanian, tukang kebun, dll."

Kehadiran Bagus Agro Pelaga dan Bali Eco Village selain membuka lapangan pekerjaan bagi penduduk sekitar tempat wisata, seiring dengan keberlanjutan usahanya, diharapkan akan berdampak pula bagi peningkatan kesejahteraan masyarakat di sekitarnya. Wisatawan yang menginap di Bagus Agro Pelaga dan Bali Eco Village, selain berwisata didalam obyek agrowisata, biasanya mereka mengunjungi desa - desa sekitar, melihat - lihat pertanian masyarakat, melihat kehidupan sosial masyarakat pedesaan dengan budaya lokalnya bahkan tidak jarang mereka menginap 1 sampai 3 hari bahkan ada yang sampai seminggu di rumah - rumah penduduk untuk bisa berinteraksi lebih dekat dengan penduduk lokal seperti di Rumah Bapak Made Warsa di Banjar Kiadan, Desa Pelaga.

Kehadiran wisatawan di tengah - tengah masyarakat memberikan kesempatan bagi masyarakat lokal untuk berusaha dengan menyediakan jasa dan menjual produk - produk pertanian guna memenuhi kebutuhan wisatawan. 
Terwujudnya kerjasama kemitraan dalam kegiatan pariwisata juga akan berdampak bagi peningkatan pendapatan masyarakat sekitarnya.

\section{Kebijakan Pemerintah Berpengaruh Tidak Langsung terhadap Pengembangan Agrowisata melalui Entrepreneurship}

Pengaruh kebijakan pemerintah terhadap pengembangan agrowisata melalui entrepreneurship memiliki koefisien regresi sebesar 0,207 (0,414 dibagi dua), dengan nilai $p$-values 0,000 yang lebih kecil dari 0,05 . Nilai $t$-statistic juga lebih besar dari 1,67 yaitu senilai 3,524. Jadi, secara tidak langsung kebijakan pemerintah berpengaruh signifikan terhadap pengembangan agrowisata melalui entrepreneurship. Kebijakan pemerintah dengan permberdayaan masyarakat melalui pembinaan, pelatihan dan pendampingan akan mampu meningkatkan kewirausahaan. Meningkatnya kewirausahaan secara tidak langsung akan mempengaruhi pengembangan agrowisata, karena lebih mampu memberikan pelayanan yang lebih baik kepada wisatawan.

\section{Kebijakan Pemerintah Berpengaruh Tidak Langsung terhadap Pengembangan Agrowisata melalui Infrastruktur}

Pengaruh kebijakan pemerintah terhadap pengembangan agrowisata melalui infrastruktur memiliki koefisien regresi sebesar 0,207 (0,414 dibagi dua), dengan nilai $p$-values 0,000 yang lebih kecil dari 0,05 . Nilai $t$-statistic juga lebih besar dari 1,67 yaitu senilai 3,524. Jadi, secara tidak langsung kebijakan pemerintah berpengaruh signifikan terhadap pengembangan agrowisata melalui infrastruktur. Kebijakan pemerintah dengan penyediaan infrastruktur seperti jalan, listrik, air bersih dan telekomunikasi yang memadai dapat memperlancar kegiatan perekonomian masyarakat dan menarik minat wisatawan untuk berkunjung ke 
tempat wisata sehingga secara tidak langsung mempengaruhi pengembangan agrowisata.

Kebijakan Pemerintah Berpengaruh Tidak Langsung terhadap Kesejahteraan Masyarakat di Kecamatan Petang, Kabupaten Badung melalui Pengembangan Agrowisata

Pengaruh kebijakan pemerintah terhadap kesejahteraan masyarakat di Kecamatan Petang, Kabupaten Badung melalui pengembangan agrowisata memiliki koefisien regresi sebesar 0,378 , dengan nilai p-values 0,002 yang lebih kecil dari 0,05. Nilai $t$-statistic juga lebih besar dari 1,67 yaitu senilai 3,042. Jadi, secara tidak langsung kebijakan pemerintah berpengaruh signifikan terhadap kesejahteraan masyarakat di Kecamatan Petang, Kabupaten Badung melalui pengembangan agrowisata.

Meningkatnya kebijakan pemerintah lewat promosi, peningkatan kualitas sumber daya dan penyediaan infrastruktur yang memadai mampu meningkatkan pengembangan agrowisata. Meningkatnya pengembangan agrowisata akan berdampak secara tidak langsung terhadap kesejahteraan masyarakat, dikarenakan mampu menarik kedatangan wisatawan dan berdampak bagi peningkatan pendapatan masyarakat yang bekerja di obyek agrowisata dan juga berdampak pada peningkatan pendapatan masyarakat di sekitarnya dengan memanfaatkan peluang - peluang usaha yang muncul dari kehadiran wisatawan di daerahnya.

Entrepreneurship Berpengaruh Tidak Langsung terhadap Kesejahteraan Masyarakat di Kecamatan Petang, Kabupaten Badung melalui Pengembangan Agrowisata

Pengaruh entrepreneurship terhadap kesejahteraan masyarakat di Kecamatan Petang, Kabupaten Badung melalui pengembangan agrowisata 
memiliki koefisien regresi sebesar 0,196 , dengan nilai $p$-values 0,023 yang lebih kecil dari 0,05. Nilai $t$-statistic juga lebih besar dari 1,67 yaitu senilai 2,282. Jadi, secara tidak langsung entrepreneurship berpengaruh signifikan terhadap kesejahteraan masyarakat di Kecamatan Petang, Kabupaten Badung melalui pengembangan agrowisata. Meningkatnya kewirausahaan akan mampu meningkatkan produktifitas sehingga mempengaruhi pengembangan agrowisata. Meningkatnya pengembangan agrowisata secara tidak langsung berdampak bagi peningkatan kesejahteraan masyarakat.

Infrastruktur Berpengaruh Tidak Langsung terhadap Kesejahteraan Masyarakat di Kecamatan Petang, Kabupaten Badung melalui Pengembangan Agrowisata

Pengaruh infrastruktur terhadap kesejahteraan masyarakat di Kecamatan Petang, Kabupaten Badung melalui pengembangan agrowisata memiliki koefisien regresi sebesar 0,251, dengan nilai p-values 0,001 yang lebih kecil dari 0,05. Nilai t-statistic juga lebih besar dari 1,67 yaitu senilai 3,361. Jadi, secara tidak langsung infrastruktur berpengaruh signifikan terhadap kesejahteraan masyarakat di Kecamatan Petang, Kabupaten Badung melalui pengembangan agrowisata.

Ketersediaan infrastruktur yang memadai seperti jalan, listrik, air bersih dan telekomunikasi serta penunjuk arah, papan informasi wisata, rambu lalu lintas wisata akan mendukung pengembangan agrowisata karena akan lebih menarik kunjungan wisatawan. Dengan meningkatnya pengembangan agrowisata akan berdampak secara tidak langsung pada peningkatan kesejahteraan masyarakat.

\section{SIMPULAN DAN SARAN}

\section{Simpulan}


Simpulan penelitian ini adalah : 1) Kebijakan pemerintah secara langsung berpengaruh positif dan signifikan terhadap entrepreneurship yang berarti meningkatnya kebijakan pemerintah akan dapat meningkatkan kewirausahaan melalui pendidikan dan pelatihan kewirausahaan. 2) Kebijakan pemerintah secara langsung berpengaruh positif dan signifikan terhadap infrastruktur yang berarti meningkatnya kebijakan pemerintah akan dapat meningkatkan ketersediaan infrastruktur yang lebih memadai seperti jalan, listrik, air bersih dan telekomunikasi, serta penunjuk arah, papan informasi wisata, rambu lalu lintas wisata. 3) Kebijakan pemerintah secara langsung tidak berpengaruh signifikan terhadap pengembangan agrowisata artinya kebijakan pemerintah kurang dapat meningkatkan pengembangan agrowisata dikarenakan kebijakan pemerintah belum optimal dalam hal promosi terhadap obyek agrowisata dan produk pertanian masyarakat lokal. Pemerintah dapat membuat terobosan baru dengan melakukan promosi secara digital yang tidak hanya fokus pada informasi produk pariwisata, tetapi juga terjalin hubungan baik antar pelaku pariwisata dengan wisatawan. 4) Entrepreneurship secara langsung berpengaruh positif dan signifikan terhadap pengembangan agrowisata berarti meningkatnya kewirausahaan akan meningkatkan pengembangan agrowisata dikarenakan mampu meningkatkan produktivitas kerja dalam mengembangkan agrowisata. 5) Infrastruktur secara langsung berpengaruh positif dan signifikan terhadap pengembangan agrowisata yang berarti meningkatnya ketersediaan infrastruktur yang memadai meliputi jalan, listrik, air bersih dan telekomunikasi, serta penunjuk arah, papan informasi wisata, rambu lalu lintas wisata akan 
meningkatkan pengembangan agrowisata, karena mampu memberikan kemudahan dan pelayanan lebih baik bagi wisatawan. 6) Pengembangan agrowisata secara langsung berpengaruh positif dan signifikan terhadap kesejahteraan masyarakat di Kecamatan Petang, Kabupaten Badung artinya semakin meningkat pengembangan agrowisata akan meningkatkan kesejahteraan masyarakat di Kecamatan Petang, Kabupaten Badung, melalui penyediaan lapangan kerja seperti pengolah lahan pertanian di obyek agrowisata, gardener and estetika, maintenance and security, food and beverage, housekeeping, front office, admin dan pemandu wisata, serta pemanfaatan peluang dari kehadiran wisatawan dalam penyediaan jasa dan produk untuk memenuhi kebutuhan wisatawan. 7) Kebijakan pemerintah berpengaruh signifikan secara tidak langsung terhadap pengembangan agrowisata melalui entrepreneurship artinya meningkatnya kebijakan pemerintah akan dapat meningkatkan kewirausahaan dan secara tidak langsung dapat meningkatkan pengembangan agrowisata. 8) Kebijakan pemerintah berpengaruh signifikan secara tidak langsung terhadap pengembangan agrowisata melalui infrastruktur artinya meningkatnya kebijakan pemerintah akan meningkatkan ketersediaan infrastruktur yang memadai dan secara tidak langsung dapat meningkatkan pengembangan agrowisata. 9) Kebijakan pemerintah berpengaruh signifikan secara tidak langsung terhadap kesejahteraan masyarakat di Kecamatan Petang, Kabupaten Badung melalui pengembangan agrowisata yang artinya bahwa meningkatnya kebijakan pemerintah akan meningkatkan pengembangan agrowisata dan secara tidak langsung dapat meningkatkan kesejahteraan masyarakat di Kecamatan Petang, Kabupaten Badung. 10) Entrepreneurship 
berpengaruh signifikan secara tidak langsung terhadap kesejahteraan masyarakat di Kecamatan Petang, Kabupaten Badung melalui pengembangan agrowisata artinya meningkatnya kewirausahaan akan meningkatkan pengembangan agrowisata dan secara tidak langsung dapat meningkatkan kesejahteraan masyarakat di Kecamatan Petang, Kabupaten Badung. 11) Infrastruktur berpengaruh signifikan secara tidak langsung terhadap kesejahteraan masyarakat di Kecamatan Petang, Kabupaten Badung melalui pengembangan agrowisata artinya meningkatnya ketersediaan infrastruktur akan meningkatkan pengembangan agrowisata dan secara tidak langsung dapat meningkatkan kesejahteraan masyarakat di Kecamatan Petang, Kabupaten Badung.

\section{Saran}

1) Pemerintah dapat melakukan terobosan dalam bidang promosi dengan membuat Tourist Information Center dalam bentuk digital yang terhubung dengan media sosial. Pelaku pariwisata dan para pengguna media sosial dapat saling memberi informasi, sehingga wisatawan mendapatkan informasi pariwisata yang cepat dan akurat, serta terjalin hubungan yang baik antara pelaku pariwisata dan wisatawan. 2) Pemerintah harus berusaha keras membangkitkan usaha - usaha agrowisata dengan membangun desa wisata yang bercirikan agrowisata dan kearifan lokal, juga dibarengi dengan peningkatan kualitas sumber daya manusia melalui pengembangan kewirausahaan dengan mengadakan pelatihan dan pendampingan yang lebih serius terhadap usaha - usaha yang berkembang di masyarakat, serta pemerintah dapat bekerjasama dengan pihak swasta membuat paket - paket wisata menarik ke Badung Utara, desa wisata dijadikan sebagai 
bagian dari paket wisata yang wajib dikunjungi, sehingga secara rutin dapat menghadirkan wisatawan yang berdampak bagi peningkatan perekonomian dan kesejahteraan masyarakat. 3) Pemerintah dapat mengembangkan agrowisata yang menerapkan prinsip - prinsip Community Based Tourism (CBT), karena memberi dampak yang lebih terutama dalam penyerapan lapangan kerja dan menghindari terjadinya perpindahan kepemilikan serta melindungi lahan pertanian.

\section{REFERENSI}

Adyana,I G.L.A., Purnami,Ni Made. 2016. Pengaruh Pendidikan Kewirausahaan, Self Efficacy dan Locus of Control pada Niat Berwirausaha. E-Jurnal Manajemen Unud, 5 (2) :1160-1188.

Bascavusoglu-Moreau,E., Kopera,S.,\& Wszendybyt-Skulska E. 2013.The Role of Creativity in Development of Innovation in Tourism. Jurnal of Entrepreneurship, Management and Innovation JEMI, 9 ( 1): 5-15.

Badan Pusat Statistik Kabupaten Badung. 2015. Badung Dalam Angka in Figures 2015.CV. Bhineka Karya.Denpasar.

Booth, A. 1990. The Tourism Boom in Indonesia. Bulletin of Indonesian Economic Studies, 26(3):45-73.

Diener, E., Oishi, S., \& Lucas, R.E. 2003. Personality culture, and subjective well- being: emotional and cognitive evaluation of life. Annual Review of Psychology, 54 :403-425.

Dinata, K. I Ketut.,Sardiana, I Ketut.,Siti, Ni Wayan. 2011. Pemberdayaan Potensi Masyarakat di Kecamatan Petang.

Dumasari,Watemin. 2013. Karakteristik Sosial Ekonomi Petani Miskin dalam Pengelolaan Usaha Mikro "Tourism Souvenir Goods" MIMBAR, 29 (2): 205-214.

Evita,R.,Sirtha, I N., Sunartha, I N. 2012. Dampak Perkembangan Pembangunan Sarana Akomodasi Wisata terhadap Pariwisata Berkelanjutan di Bali. Jurnal Ilmiah Pariwisata, 2(1):109-222. 
Firmasyah,R.,Pratiwi,R.N.,Riyanto. 2014. Strategi Pemerintah Daerah dalam Pemberdayaan Usaha Mikro, Kecil dan Menengah di Kabupaten Madiun (Studi pada Dinas Koperasi, Perindustrian, Perdagangan dan Pariwisata Kabupaten Madiun dan Sentra Industri Brem Desa Kaliabu, Kecamatan Mejayan, Kabupaten Badung).Jurnal Administrasi Publik (JAP), 2 (1):154 160.

Hadiyati, E. 2011. Kreativitas dan Inovasi Berpengaruh Terhadap Kewirausahaan Usaha Kecil. Jurnal Manajemen dan Kewirausahaan,13(1), p: 8-16.

Hampton, M. P. \& Jeyacheya, J. 2015. Power, Ownership and Tourism in Small Islands: Evidence from Indonesia. Jurnal World Development, 70:481-495.

Indrawan, M.I. 2008. Analisis Kondisi Infrastruktur Perekonomian terhadap Produktivitas Dunia Usaha Kota Medan. Jurnal Ilmiah Abadi Ilmu,1(1):7582.

Kapteyn, Arie., Smith, James. P. \& van Soest, Arthur. 2009.Life Satisfaction. IZA Discussion Paper No. 4015.

Lobo, R. E., Goldman, G. E., Jolly, D. A., Wallace, B. D., Schrader, W. L., \& Parker, S. A. 1999. Agricultural tourism: agritourism benefits agriculture in San Diego County. Retrieved June 4, 2008, from the University of California-Davis Small Farm Center Web site: http://www.sfc.ucdavis.edu/agritourism/agritourSD.html

Luthfi, R. R. 2013. Peran Pariwisata terhadap Kesejahteraan Masyarakat di Sektor lapangan Pekerjaan dan Perekonomian Tahun 2009 -2013. Jurnal Ilmiah Fakultas Ekonomi dan Bisnis Universitas Brawijaya.

Munizu,M. 2010. Faktor - Faktor Eksternal dan Internal Terhadap Kinerja Usaha Mikro dan Kecil di Sulawesi Selatan. Jurnal Manajemen dan Kewirausahaan, 12 (1) : 33-4.

Mouw,E., Djurubasa.G.M.P. 2014. Implementasi Kebijakan Program Festival Teluk Jailolo Di Kabupaten Halmahera Barat. Jurnal UNIERA, 3 (1).

Nehen, Ketut. 2012. Perekonomian Indonesia, penerbit Udayana University Press, Bali.

Parma, I Putu Gede. 2013. Pengembangan Pariwisata Berkelanjutan Berdasarkan Perspektif Tata Ruang di Bali. Jurnal Jurusan Perhotelan,10 (2).

Peraturan Daerah Kabupaten Badung Nomor 26 Tahun 2013. Rencana Tata Ruang Kabupaten Badung Tahun 2013 - 2033. Mangupura 
Picard, M. 1996. Cultural tourism and touristic culture. Singapore: Archipelago Press, [translated by D. Darling]

Pitana. 2011."Pemberdayaan dan Hiperdemokrasi dalam Pembangunan Pariwisata"e, dalam I Nyoman Darma Putra dan I Gde Pitana (ed). Pemberdayaan dan Hiperdemokrasi dalam Pembangunan Pariwisata, pp: 1-27. Denpasar: Pustaka Larasan.

Rahimah,N.S., dan Putro,H.P.H. 2014. Pengaruh Infrastruktur Jalan Terhadap Sebaran Investasi di Provinsi Jawa Barat. Jurnal Perencanaan Wilayah dan Kota 2 SAPPK V3N3:663 -670.

Rotinsolu D.,Sunusi D.K., daan Kumenaung K. 2014. Analisis Pengaruh Jumlah Tenaga Kerja, Tingkat Pendidikan, Pengeluaran Pemerintah pada Pertumbuhan Ekonomi dan Dampaknya terhadap Kemsikinan di Sulawesi Utara Tahun 2001-2010. Jurnal Berkala Ilmiah Efisiensi, 14 (2)

Samiadji, Sanusi.A.,Manan, A. 2014. Influence of Government on Perfomance Business by Entrepreneur Orientation and Environment Adaptability Small Medium Enterprice Chips Industry. IOSR Journal of Business and Management (IOSR-JBM), 16 (11):40-45.

Scheyvens, Regina, 2002. Tourism for Development (Empowering Communities), England: Pearson Education Asia Pte Ltd. , 2011. Tourism and poverty. London: Routledge.

Seetanah B., Juwaheer T. D., Lamport M. J., Rojid S., Sannasse R. V. and SubadasA.U. 2011. Does Infrastructure Matter in Tourism Development? University of Maritius Research Journal 17:89 - 107.

Sharpley, R. 2000. Tourism and Sustainable Development: Exploring the Theoretical Divide. Journal of Sustainable Development.

Suansri, Potjana. 2003. Community Based Tourism Handbook. Thailand : REST Project.

Sudiarta,M. 2005.Dampak Fisik, Ekonomi, Sosial Budaya Terhadap Pembangunan Pariwisata di Desa Serangan Denpasar Bali. Jurnal Manajemen Pariwisata,4(2):111-129.

Tim Nasional Percepatan Penanggulangan Kemiskinan (TNP2K).2016.Jumlah Rumah Tangga dan Individu menurut Status Kesejahteraan Seluruh Indonesia. www.tnp2k.go.id/ 
Umami,Z. 2015. Social Strategy pada Media Sosial untuk Promosi Pariwitsa Dearah Istimewa Yogyakarta. Jurnal Interaksi,4 (2):195-201.

Utama, I Gusti Bagus Rai. 2011. Agrowisata Sebagai Pariwisata Alternatif di Indonesia.

Valeriani, D. 2011. Analisis Pengaruh Kebijakan Infrastruktur Terhadap Pendapatan Perkapita Masyarakat Kabupaten Bangka Provinsi Kepulauan Bangka Belitung. Jurnal Equity, 1(5)

Wahyudin,U. 2012. Pelatihan Kewirausahaan Berlatar Ekokultural untuk Pemberdayaan Masyarakat Miskin Pedesaan. Jurnal MIMBAR,28 (1): 5564.

Waspada, I. 2008. Potensi Pariwisata Berbasis Agrotechnopark (ATV) di Jawa Barat Selatan (Studi Pariwisata di Kolaberes, Cianjur Selatan). Jurnal Pendidikan Geografi (GEA), 8 (1).

Widiarta, I Nyoman. 2015. "Pengelolaan Daya Tarik Wisata Pura Taman Ayun sebagai Bagian dari Warisan Budaya Dunia" (tesis). Denpasar: Universitas Udayana.

Wulandari W. 2014. Dampak Kebijakan Perizinan Investasi Bidang Pariwisata (Obyek dan Daya Tarik Wisata) terhadap Perekonomian Kota Wisata Batu Tahun 2010-2013. Jurnal Ilmiah Fakultas Ekonomi dan Bisnis Universitas Brawijaya.

Zimmerer, Thomas W., Scarborough, Norman N., \& Wilson, Doug. 2008. Essentials of entrepreneurship and small business management, 5th ed. Translated by Deny Arnos Kwary. Jakarta: Salemba Empat.

Zoto, S., Qirici, E., Polena, E. 2013. Agrotourism - A Sustainable Development for Rural Area of Korca. Jurnal European Academic Research, 1:210-223. 